\title{
Thoracic Gas Volume
}

National Cancer Institute

\section{Source}

National Cancer Institute. Thoracic Gas Volume. NCI Thesaurus. Code C124426.

The absolute volume of gas contained in the thoracic cavity at any given point in time and at any level of alveolar pressure. 